\title{
Water-Level Trends in Aquifers of South Carolina
}

\author{
Scott V. Harder, Joseph A. Gellici and Andrew Wachob
}

AUTHORS: South Carolina Department of Natural Resources, Columbia, South Carolina, 29201, USA.

REFERENCE: Proceedings of the 2012 South Carolina Water Resources Conference, held October 10-11, 2012 at the

Columbia Metropolitan Convention Center.

\begin{abstract}
Groundwater levels are examined to document and evaluate short- and long-term trends observed in each of the major aquifers in the State. Data are compiled from groundwater-monitoring networks maintained by the South Carolina Department of Natural Resources (DNR), the South Carolina Department of Health and Environmental Control (DHEC), and the United States Geological Survey (USGS). The data are used in the support of groundwater management and allocation, assessment of droughts, groundwater-flow modeling, and resource assessment. Hydrographs from approximately 170 wells are reviewed with periods of record ranging from 1 to 56 years.

Water levels across most of the State were affected by droughts occurring from 1998-2002 and from 20072008. In the Piedmont, water-level declines varied substantially from 1 to over $10 \mathrm{ft}$ during these drought periods. Though water levels typically returned to baseline levels in many wells, several sites experienced little to no recovery with overall downward trends of
\end{abstract} 10 to $12 \mathrm{ft}$ from 2000 to 2012 .

Middendorf aquifer levels in eastern Berkeley County have declined by approximately $55 \mathrm{ft}$ since the early 1990s. In southern Florence County and southern Lexington County, water levels have declined by approximately $10 \mathrm{ft}$ in the Middendorf aquifer with little to no recovery after the 1998-2002 and 2007-2008 droughts. Similar declines are noted in the Middendorf aquifer in Aiken, Allendale, and Barnwell Counties, where water levels have dropped 3 to $10 \mathrm{ft}$ since the mid-1990s.

In the Black Creek aquifer, water levels in southern Marion County and southern Florence County have declined by $40 \mathrm{ft}$ and $16 \mathrm{ft}$ over their respective periods of record. In Aiken, Allendale, and Barnwell Counties, water levels have dropped 4 to $12 \mathrm{ft}$ in the Black Creek aquifer since the mid-1990s, similar to declines observed in the Middendorf aquifer in these counties.
Water levels in the Tertiary sand aquifer have declined 6 to $15 \mathrm{ft}$ in Allendale and Barnwell Counties since the mid-1990s, similar to patterns observed in the Middendorf and Black Creek aquifers in these counties. This pattern suggests that aquifers have not fully recovered to levels observed before the 19982002 drought.

Floridan aquifer water levels have experienced a leveling off or a slight recovery during the past ten years after steady declines throughout the 1970s and 1980s at several wells sites in Beaufort County. Observations in southern Colleton County and southern Charleston County indicate water-level declines in the Floridan aquifer of about 8 and $12 \mathrm{ft}$, respectively, since 2000 . Observations in central Charleston County indicate a decline of about $20 \mathrm{ft}$ since the early 1980s, while observations in northern Colleton County indicate a decline of about $20 \mathrm{ft}$ since the late 1970s.

\section{INTRODUCTION}

The South Carolina Department of Natural Resources (DNR) routinely collects groundwater-level data for water-resource assessments and for management and planning purposes. These data are used to identify short- and long-term changes in groundwater levels and storage due to changes in withdrawals, recharge rates, and climatic conditions; to calibrate groundwater-flow models; and to determine regional hydraulic gradients and groundwater-flow rates and directions of the major aquifers. DNR's base groundwater-monitoring network currently includes 122 wells (Figure 1). Water levels of 86 wells are measured hourly with automated data recorders (ADRs); the remaining wells are measured periodically, typically on a bimonthly basis, using an electric measuring tape. Most monitoring wells have been measured since the mid-to-late 1990s, although a number of wells existed before then, one dating back to 1955 . 


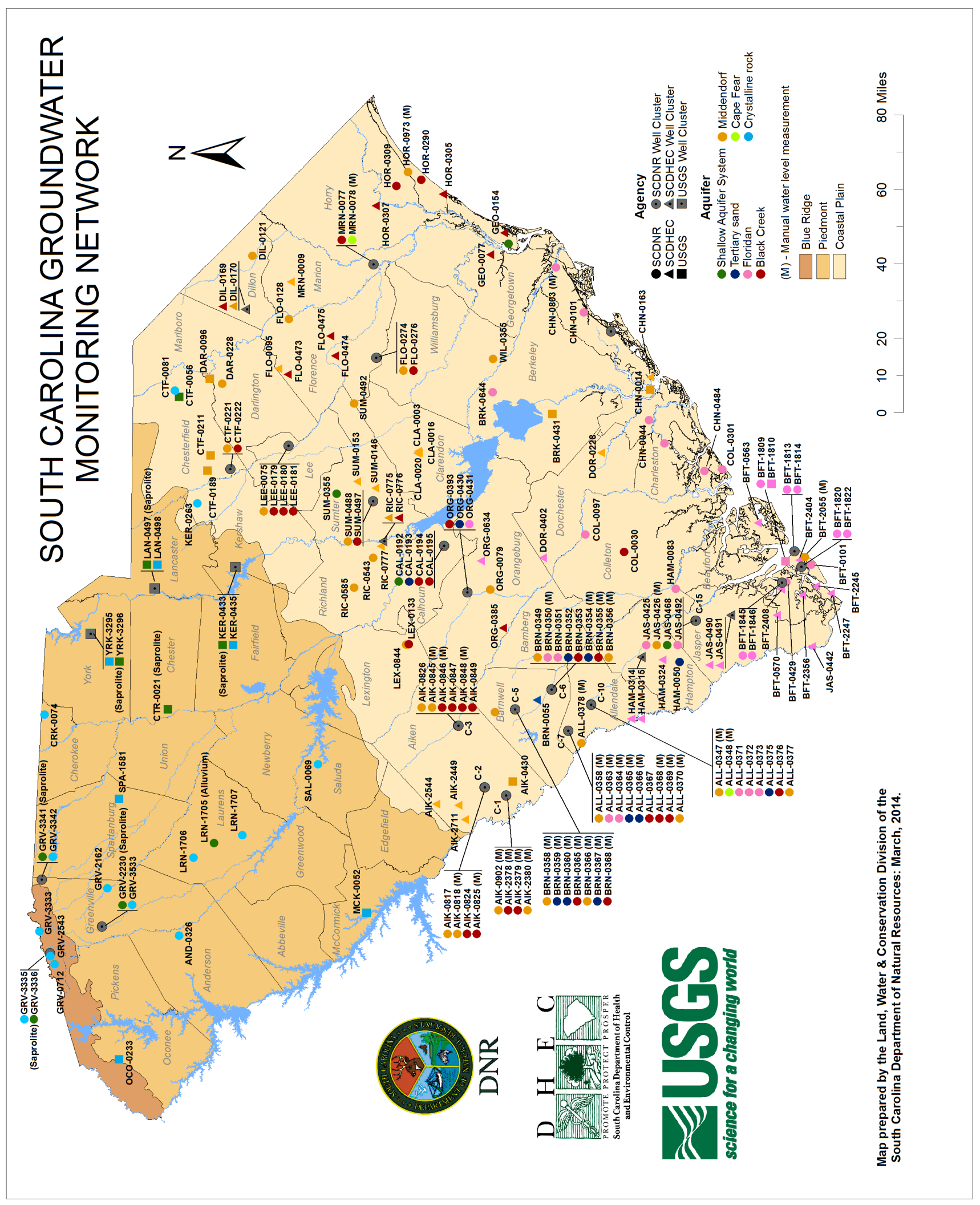

Figure 1. South Carolina groundwater monitoring network. 
Reported groundwater use for the State as a whole has shown no noticeable trend from 2002 to 2012, and exhibits annual fluctuations indicative of climate conditions. Reported irrigation on a statewide basis has increased noticeably over the same period, while reported industrial use has declined. Reported groundwater use for water supply has also shown little no noticeable trend from 2002 to 2012 . However, the potential for significant increases in groundwater use for agricultural and golf course irrigation, industry, energy production, and public water supply over the next several decades stresses the need for long-term groundwater-level monitoring. In addition, recent multi-year droughts from 1998-2002 and 20072008 have highlighted the importance of long-term groundwater-level data in the assessment of ground water resources.

The DNR well network is part of a collaborative monitoring effort with the Department of Health and Environmental Control (DHEC) and the United States Geological Survey (USGS). The goal of this cooperative effort is to develop and maintain a statewide groundwater-monitoring network that provides scientifically defensible information for use in planning, managing, and developing South Carolina's groundwater resources in a responsible and sustainable manner for all current and future users. DHEC currently maintains 41 continuous groundwater level monitoring sites, while USGS maintains 18 sites.

The background and methods described in this study are for the DNR monitoring network. Groundwater level trends are discussed mainly for those wells in the DNR network; however, several USGS sites are referenced as well. Periods of record for wells in the DHEC network only range from 1 to 6 years, and hence, are too short to adequately evaluate trends. Wells sites for all three agencies are illustrated in Figure 1.

\section{RELATED WORK}

DNR has published a series of reports documenting groundwater-level data collected from the DNR monitoring network. Harwell and others (2004) documents water-level data collected from 56 wells during the period from 2000 through 2001. Agerton and others (2007) contains water-level data collected from 69 wells during the period from 2000 through 2005. Other groundwater-level compilations include intermittent and periodic water-level measurements of 16 Piedmont province wells and 266 Coastal Plain province wells by Waters (2003). That report represents 282 hydrographs and is the most extensive compilation of historical South Carolina groundwater-level data to date. Hydrograph records range from 6 to 50 years, and about one-third of the record sets span periods greater than 20 years. Gellici and others (2004) published selected groundwater data illustrating the effects of the 1998-2002 drought. More recently, Harder and others (2012) published groundwater-level data for 109 wells for the period from 2006 through 2010 and also reviewed groundwater-level trends for the all the major aquifers in the state.

\section{METHODS}

\section{Well Numbering Systems and Hydrogeologic Framework}

Wells are identified by a county well number. The county well number consists of a county-name abbreviation (Table 1) and a sequential number that is assigned by the DNR in coordination with USGS. For example, SAL-0069 represents the sixty-ninth well inventoried by the DNR in Saluda County.

Table 1. County-name abbreviations for monitoring network.

\begin{tabular}{|l|l|l|l|}
\hline County & Abbreviation & County & Abbreviation \\
\hline Abbeville & ABB & Greenwood & GNW \\
\hline Aiken & AIK & Hampton & HAM \\
\hline Allendale & ALL & Horry & HOR \\
\hline Anderson & AND & Jasper & JAS \\
\hline Bamberg & BAM & Kershaw & KER \\
\hline Barnwell & BRN & Lancaster & LAN \\
\hline Beaufort & BFT & Laurens & LRN \\
\hline Berkeley & BRK & Lee & LEE \\
\hline Calhoun & CAL & Lexington & LEX \\
\hline Charleston & CHN & Marion & MRN \\
\hline Cherokee & CRK & Marlboro & MLB \\
\hline Chester & CTR & McCormick & MCK \\
\hline Chesterfield & CTF & Newberry & NEW \\
\hline Clarendon & CLA & Oconee & OCO \\
\hline Colleton & COL & Orangeburg & ORG \\
\hline Darlington & DAR & Pickens & PCK \\
\hline Dillon & DIL & Richland & RIC \\
\hline Dorchester & DOR & Saluda & SAL \\
\hline Edgefield & EDG & Spartanburg & SPA \\
\hline Fairfield & FAR & Sumter & SUM \\
\hline Florence & FLO & Union & UNI \\
\hline Georgetown & GEO & Williamsburg & WIL \\
\hline Greenville & GRV & York & YRK \\
\hline
\end{tabular}


The hydrogeologic framework used in this report is that of Aucott and others (1987). Aucott divided the Coastal Plain sedimentary sequence into six aquifers, which in ascending order are: Cape Fear, Middendorf, Black Creek, Tertiary sand, Floridan, and shallow aquifer system (surficial). In 1995, Aadland and others presented a detailed hydrogeologic characterization of the Coastal Plain sequence at the Savannah River Site (SRS) and surrounding area that resulted in a revised hydrogeologic framework and a new hydrostratigraphic nomenclature for west-central South Carolina (Aadland and others, 1995). Aquifers and confining units were named after local geographic features near type-well localities and the previous aquifer names, which were based on geologic formations, were abandoned at SRS. This revised framework and new nomenclature were extended across the rest of the Coastal Plain in the report Groundwater Availability in the Atlantic Coastal Plain of North and South Carolina in the chapter entitled "Hydrogeologic Framework of the Atlantic Coastal Plain, North and South Carolina "(Gellici and Lautier, 2010). For this report, the names and framework of Aucott and others (1987) continue to be used, but wells are also assigned to aquifers using the new framework and nomenclature described by Gellici and Lautier as well. The three hydrogeologic frameworks are summarized in Figure 2.

Aquifers in the Piedmont and Blue Ridge provinces of the state are classified as crystalline rock or shallow aquifer system. The shallow aquifer system is further differentiated as saprolite or alluvium.

\begin{tabular}{|c|c|c|c|}
\hline Updip & Downdip & Savannah River Site & Downdip from Savannah River Site \\
\hline \multirow{5}{*}{$\begin{array}{l}\text { Tertiary sand } \\
\text { aquifer } \\
\text { (upper part) }\end{array}$} & Surficial aquifer & \multirow{7}{*}{ Upper Three Runs aquifer } & Surficial aquifer \\
\hline & & & Upper Floridan confining unit \\
\hline & & & Upper Floridan aquifer \\
\hline & aquifer & & Middle Floridan confining unit \\
\hline & & & Middle Floridan aquifer \\
\hline & & & Gordon confining unit \\
\hline \multicolumn{2}{|c|}{ Tertiary sand aquifer (lower part) } & & Gordon aquifer \\
\hline \multicolumn{2}{|c|}{ unnamed confining unit } & Crouch Branch confining unit & Crouch Branch confining unit \\
\hline \multicolumn{2}{|c|}{ Black Creek aquifer } & Crouch Branch aquifer & Crouch Branch aquifer \\
\hline \multicolumn{2}{|c|}{ unnamed confining unit } & McQueen Branch confining unit & McQueen Branch confining unit \\
\hline \multicolumn{2}{|c|}{ Middendorf aquifer } & McQueen Branch aquifer & 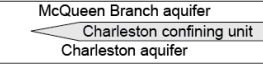 \\
\hline \multicolumn{2}{|c|}{ unnamed confining unit } & unnamed confining unit & Gramling confining unit \\
\hline \multicolumn{2}{|c|}{ Cape Fear aquifer } & & Gramling aquifer \\
\hline (Aucott an & others, 1987) & (Aadland and others, 1995) & (Gellici and Lautier, 2010) \\
\hline
\end{tabular}

Figure 2. Three hydrogeologic frameworks for South Carolina. "Updip" refers to sediments in the upper Coastal Plain; "downdip" refers to sediments in the lower Coastal Plain.

\section{Data Collection}

Groundwater-level data are presented in feet above or below land surface and measurements and sensor settings are made relative to a specified measurement point. Some of the land-surface and measuring-point elevations were surveyed from USGS or South Carolina Geodetic Survey benchmarks and are reported to the nearest tenth or hundredth of a foot using the National Geodetic Vertical Datum of 1929 (NGVD29). Elevations at other sites were taken from USGS topographic maps and estimated to the nearest foot, and are considered accurate to one-half the map contour interval. Well locations were determined with the Global Positioning System (GPS) using the North American Datum of 1983 (NAD83).

Manual measurements typically are made with electric tapes, which are capable of an accuracy of 0.01 $\mathrm{ft}$ (feet). However, visibility, thermal expansion and contraction, and tape sinuosity diminish measurement accuracy in field conditions, and accuracies, therefore, are assumed to be no better than $0.05 \mathrm{ft}$ in practice. Flowing artesian wells are manually measured with $0-30,0-60$, or $0-100$ psi (pounds per square inch) range Bourdon-type test gages. The gages are calibrated annually by a commercial testing laboratory and are rated to 0.25 percent of their respective measurement ranges.

Water-level sensors used for automated monitoring stations include shaft encoders and pressure transducers whose readings are calibrated to manual measurements. Shaft encoders measure depth to water and have a rated accuracy and resolution of $0.01 \mathrm{ft}$. The sensor reading is set in reference to a manual tape measurement; however, well plumb, casing joints, and cable disturbances can affect subsequent readings. Measurements within $0.10 \mathrm{ft}$ of a concurrent manual measurement are accepted, along with the corresponding records. Pressure transducers measure the height of water above the sensor. The sums of the transducer measurement (depth above probe) and corresponding taped measurement (depth to water) recorded at each site visit have been compared to determine transducer performance. Where the sum of measurements was found to differ by $0.2 \mathrm{ft}$ from previous measurements, a potential instrument fault may have existed, but no record correction was applied. Where the specifications were exceeded repeatedly, either instruments were recalibrated or instrument failure was confirmed. If failure was confirmed, the transducer was replaced and the associated records were excluded from the hydrograph.

Logged measurements are stored in both rawdata and processed-data tables. The raw-data table 
contains uncorrected hourly measurements and reflects the readings and the performance of various sensors as they were originally stored in data loggers. Raw data are stored mainly "as is" and are archived at DNR for insight into hardware conditions and for quality assurance. Processed-data tables are corrected for barometric pressure, where appropriate, and are winnowed of measurement anomalies and hardware failures. Average daily water level is calculated for each day having 17 or more hourly measurements.

Groundwater data presented in this report are daily averaged and/or manual values. Groundwater data and statistics are available on the DNR website at http:// www.dnr.sc.gov/water/hydro/groundwater/index.html. Additional information on the groundwater monitoring network can be found in Harder and others (2012).

\section{RESULTS}

Hydrographs are presented for the crystalline rock aquifer system in the Piedmont and Blue Ridge Provinces and for the four main aquifers of the Coastal Plain (Middendorf, Black Creek, Tertiary sand, and Floridan). The caption for each hydrograph includes the open or screened interval for the well, and in cases where the interval is unknown, the total depth of the well below land surface is listed instead. Wells constructed in crystalline rock or limestone are not generally screened and remain as an open hole, while wells constructed in unconsolidated sand sediments generally have screened casings in the aquifer(s) of interest. Nomenclatures used by both Aucott and others (1987) and Gellici and Lautier (2010) for the hydrogeologic framework are included in the figure caption for wells in the Coastal Plain.

\section{Crystalline Rock Aquifer}

Hydrographs for most wells in the Crystalline Rock aquifer show noticeable seasonal fluctuations, which can range from $1 \mathrm{ft}$ in AND-0326 (Figure 3) to $16 \mathrm{ft}$ in SAL-0069 (Figure 4). Significant declines in water levels due to the multi-year droughts of 19982002 and 2007-2008 are observed in some wells such as CRK-0074 (Figure 5), GRV-3342, and LRN-1706, but declines are less severe in other wells such as GRV2543 (Figure 6), GRV-3335, and AND-0326 (Figure 3). Most sites in the DNR network have recovered from the effects of these droughts and little to no long-term declines are observed; however, MCK-0052 and SPA1585 , both maintained by the USGS, have experienced long-term declines of over $10 \mathrm{ft}$ and $15 \mathrm{ft}$, respectively, over their 18-year periods of record.

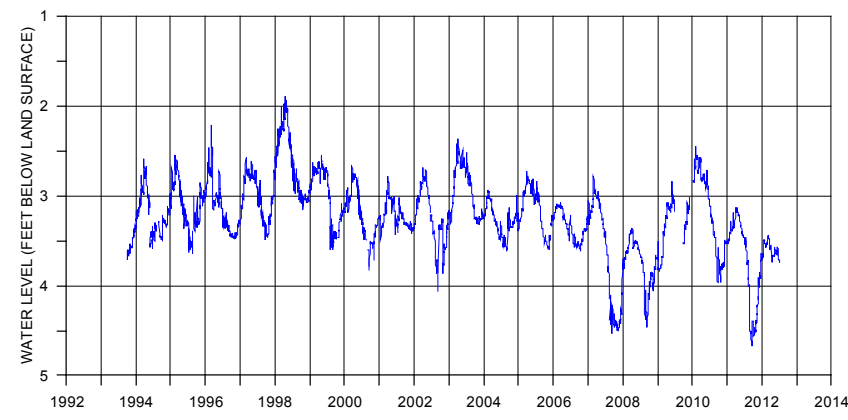

Figure 3. Daily average water levels for AND-0326 (Crystalline Rock aquifer; open hole interval 75-398 ft).

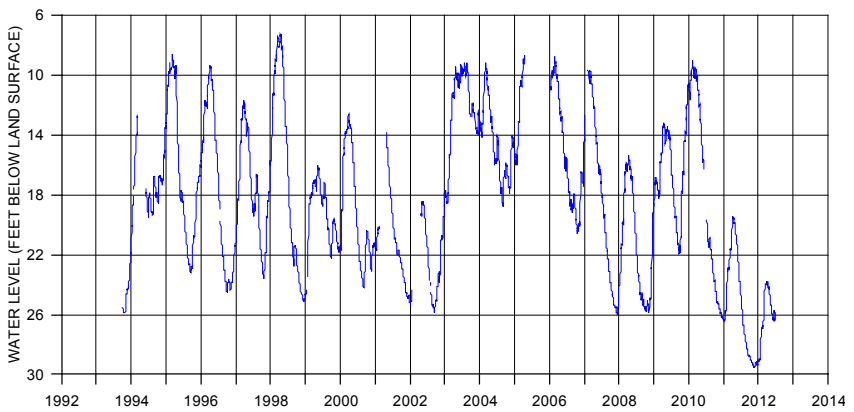

Figure 4. Daily average water levels for SAL-0069 (Crystalline Rock aquifer; open hole interval 92-480 ft).

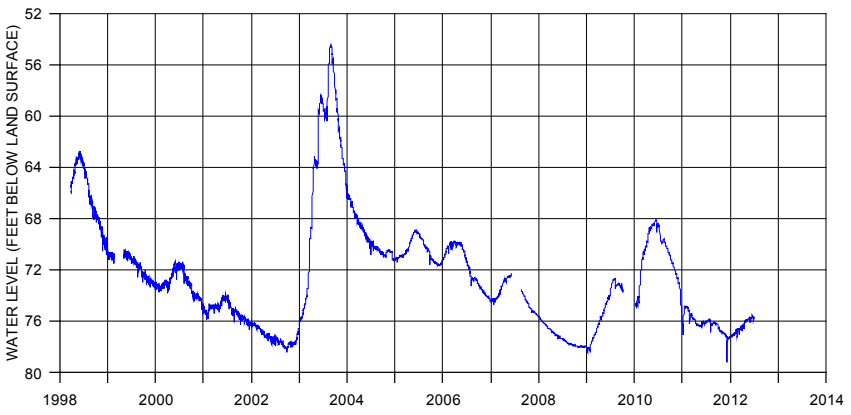

Figure 5. Daily average water levels for CRK-0074 (Crystalline Rock aquifer; open hole interval 99-265 ft).

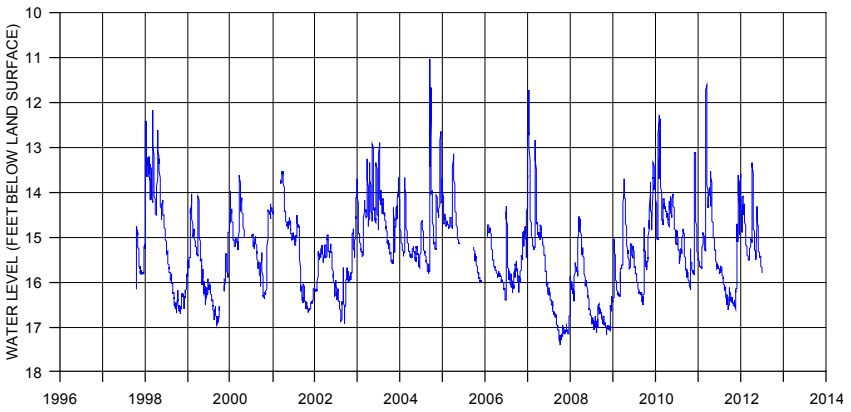

Figure 6. Daily average water levels for GRV-2543 (Crystalline Rock aquifer; total depth $50 \mathrm{ft}$ ). 


\section{Middendorf}

In southern Florence County, the water level in the Middendorf aquifer has steadily dropped about $10 \mathrm{ft}$ over the past ten years at well FLO-0274 (Figure 7) in Lake City. In southern Lexington County at well LEX0844, the water level in the Middendorf declined about $10 \mathrm{ft}$ during the 1998-2002 drought, leveled off after the drought, and has yet to fully recover to pre-drought levels (Figure 8). Similar declines are noted in the Middendorf aquifer in Aiken, Allendale, and Barnwell Counties, where water levels have dropped 3 to $10 \mathrm{ft}$ since the mid-1990s (AIK-0845, ALL-0347 and BRN0349, for example).

Well BFT-2055, at Hilton Head Island, is screened in both the Cape Fear and Middendorf aquifers; measurements therefore reflect composite water levels. They are presumed to more closely reflect Middendorf water levels, owing to that system's greater thickness and hydraulic conductivity. Consequently, BFT-2055 measurements are presented with Middendorf aquifer data. Water levels in wells BFT-2055 (Figure 9) and JAS-0426 have been declining over the past 10 years, by $28 \mathrm{ft}$ in BFT-2055 and by about $12 \mathrm{ft}$ in JAS-0426. BRK0431, a well maintained by the USGS, has experienced a decline of approximately $55 \mathrm{ft}$ since 1990 .

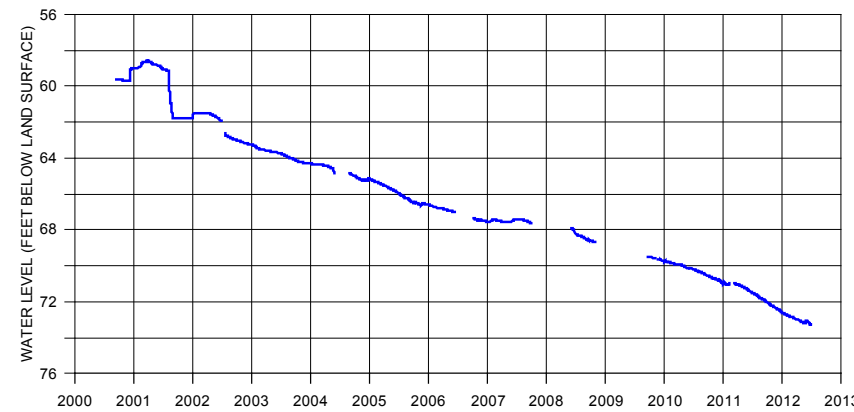

Figure 7. Daily average water levels for FLO-0274 (Middendorf/ McQueen Branch aquifer; screened interval 540-560 ft).

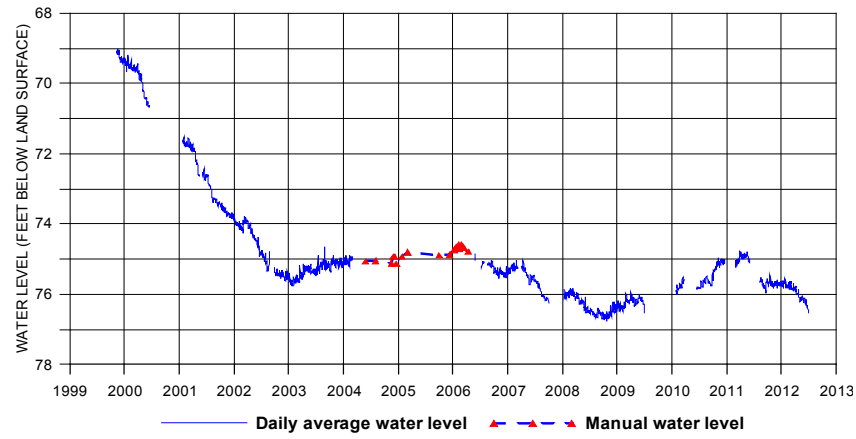

Figure 8. Daily average and manual water levels for LEX-0844 (Middendorf/McQueen Branch aquifer; screened interval 392-502 ft).
In well FLO-0128, the water level has been recovering since August 1999 when it hit an all-time low of $92.1 \mathrm{ft}$ below land surface (Figure 10). By 2010, the water level recovered to $41.2 \mathrm{ft}$ bls, as the City of Florence continues to supplement its groundwater supply with surface water from the Pee Dee River.

In contrast to the larger declines observed in the western and southern Coastal Plain, water levels in Darlington, Lee, and Richland Counties (DAR0228, LEE-0075, RIC-0543, and RIC-0585) have experienced little to no long-term decline over the past 10 to 15 years (Figure 11). Seasonal fluctuations are observed in the data from wells in these counties and have been more pronounced over the last 5 years. Drawdowns from the severe droughts from 1998-2002 and from 2007-2008 are observed as well; however, water levels typically returned to baseline levels after each of these two droughts.

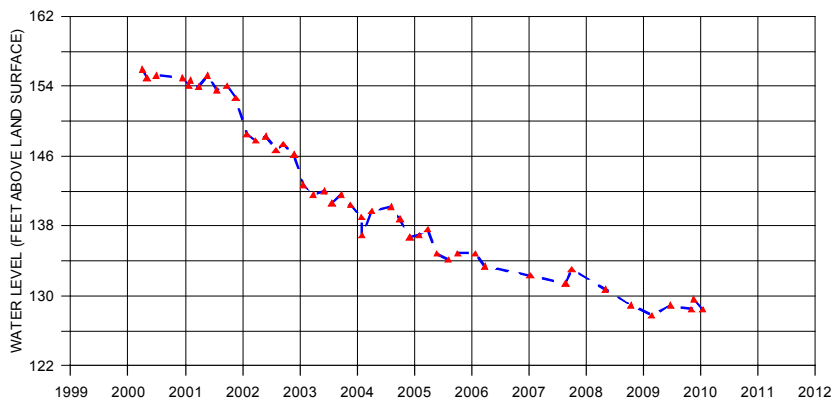

Figure 9. Manual water levels for BFT-2055 (Middendorf/ Gramling aquifer; screened interval 2,782-3,688 ft). Middendorf water levels rise above land surface at this site.

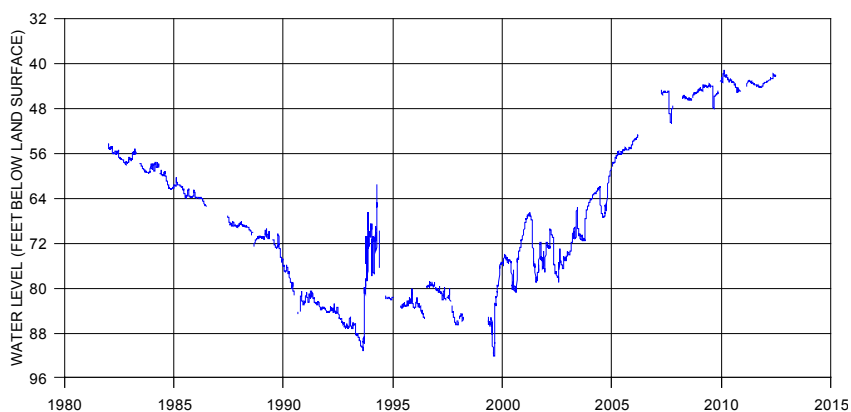

Figure 10. Daily average water levels for FLO-0128 (Middendorf/ McQueen Branch aquifer; screened interval 265-690 ft).

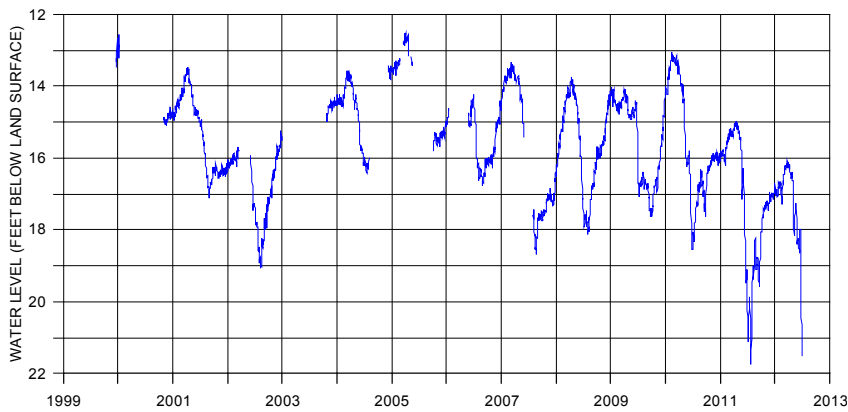

Figure 11. Daily average water levels for LEE-0075 (Middendorf/ McQueen Branch aquifer; screened interval 306-356 ft). 


\section{Black Creek}

The water level in well MRN-0077 (Figure 12), located at Britton's Neck, steadily declined about 40 ft from 1993 to 2010. Well FLO-0276 (Figure 13), in Lake City, has seen its water level drop $16 \mathrm{ft}$ from 2001 to 2010. In Aiken, Allendale, and Barnwell Counties, water levels have dropped 4 to $12 \mathrm{ft}$ in the Black Creek aquifer since the mid-1990s (AIK-0847, ALL-0367 and BRN-0355, for example), similar to declines observed in the Middendorf aquifer in these counties (Figure 14).

Water levels in COL-0030 have experienced declines of approximately $4 \mathrm{ft}$ from 1996 to 2010, while maintaining noticeable seasonal fluctuations (Figure 15). Water levels at ORG-0393 have seen longterm declines of only 1 to $2 \mathrm{ft}$ since 2001 , but the water

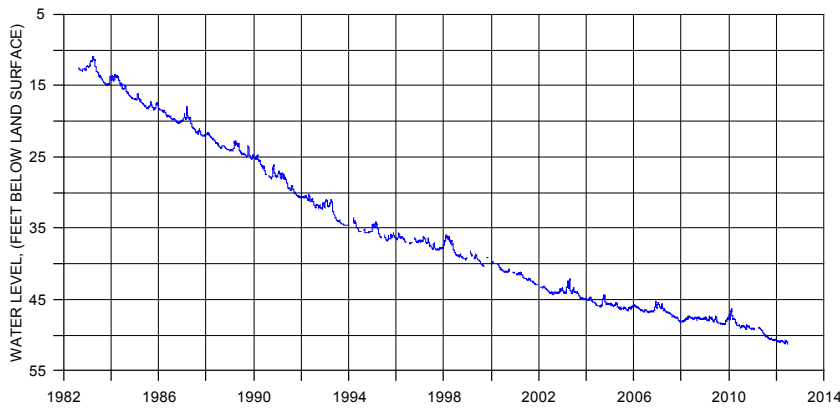

Figure 12. Daily average water levels for MRN-0077 (Black Creek/Crouch Branch aquifer; 325-355 ft).

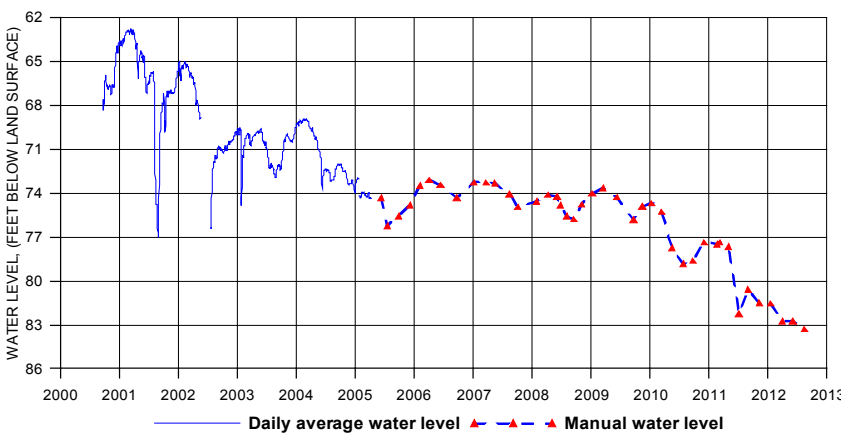

Figure 13. Daily average and manual water levels for FLO-0276 (Black Creek/Crouch Branch aquifer; screened interval 230-250 ft).

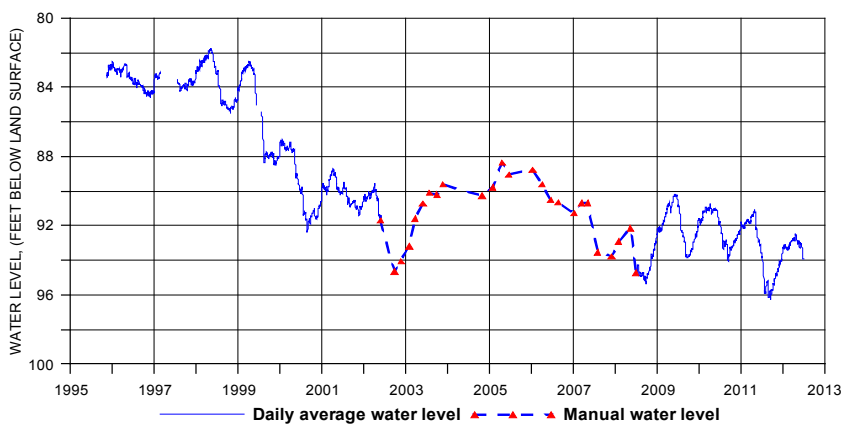

Figure 14. Daily average and manual water levels for ALL-0367 (Black Creek/Crouch Branch aquifer; screened interval 551-561 ft). levels exhibit strong seasonal fluctuations ranging from 8 to $20 \mathrm{ft}$ (Figure 16).

\section{Tertiary Sand}

Water levels in the Tertiary sand aquifer have declined about 6 to $15 \mathrm{ft}$ in Allendale (ALL-0375; Figure 17) and Barnwell Counties (BRN-0352; Figure 18) since the mid-1990s, similar to patterns observed in the Middendorf and Black Creek aquifers in these counties. This pattern suggests that aquifers have not fully recovered to levels observed before the 19982002 drought. Water levels at ORG-0430 have had smaller overall declines of 4 to $5 \mathrm{ft}$ since 2001 while maintaining strong seasonal fluctuations on the order of 8 to $10 \mathrm{ft}$ (Figure 19).

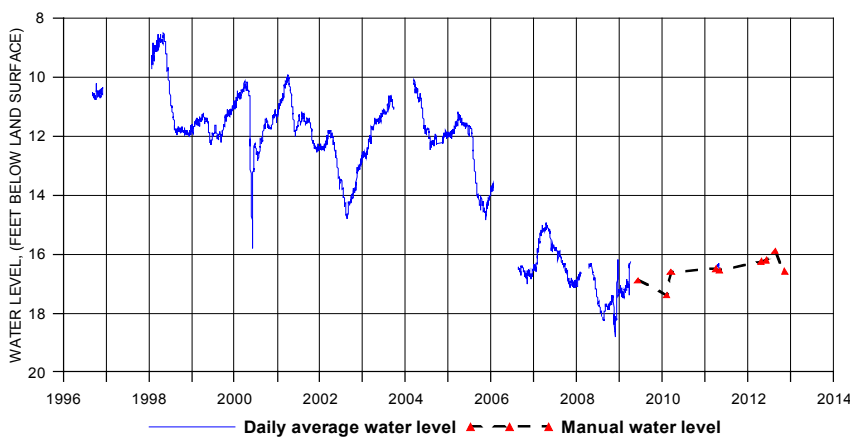

Figure 15. Daily average and manual water levels for COL-0030 (Black Creek/Crouch Branch aquifer; total depth 1,340 ft).

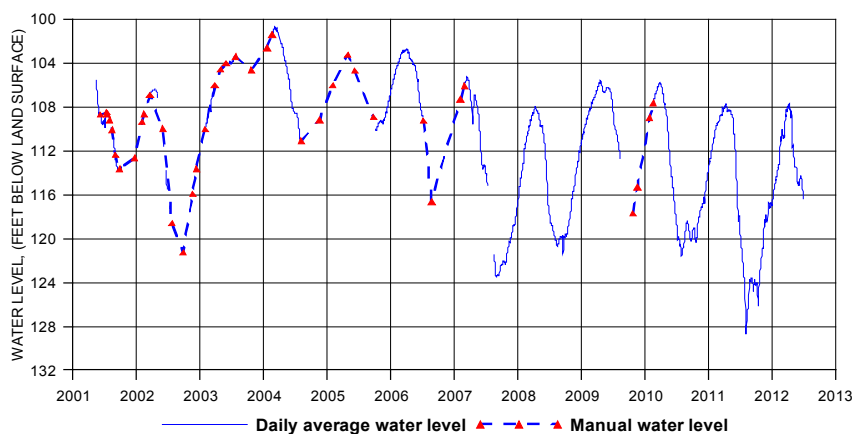

Figure 16. Daily average and manual water levels for ORG-0393 (Black Creek/Crouch Branch aquifer; screened interval 423-463 ft).

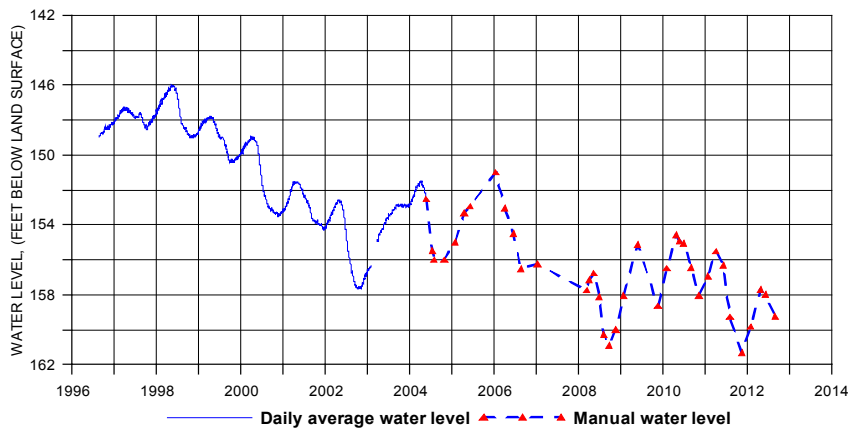

Figure 17. Daily average and manual water levels for ALL-0375 (Tertiary sand/Gordon aquifer; screened interval 453-578 ft). 


\section{Floridan}

Water levels in BFT-0101 (Figure 20) have shown a slight recovery during the past ten years after a steady decline throughout the 1970s and 1980s; however, seasonal fluctuations have increased from 1 to $2 \mathrm{ft}$ to 4 to $9 \mathrm{ft}$ during the same period. Note the longer time scale in Figure 20.

Well BFT-0429 has seen overall water levels remain steady after a decline of approximately $5 \mathrm{ft}$ during the 1970s and 1980s. Similar to BFT-0101, the magnitude of seasonal fluctuations in this well has increased from 1 to $2 \mathrm{ft}$ to 5 to $7 \mathrm{ft}$ during the past several decades.

Wells COL-0301 (Figure 21) and CHN-0484 (Figure 22), both located near Edisto Beach, have seen water-level declines of about 8 and $12 \mathrm{ft}$, respectively, since 2000 . Both of these wells also exhibit strong

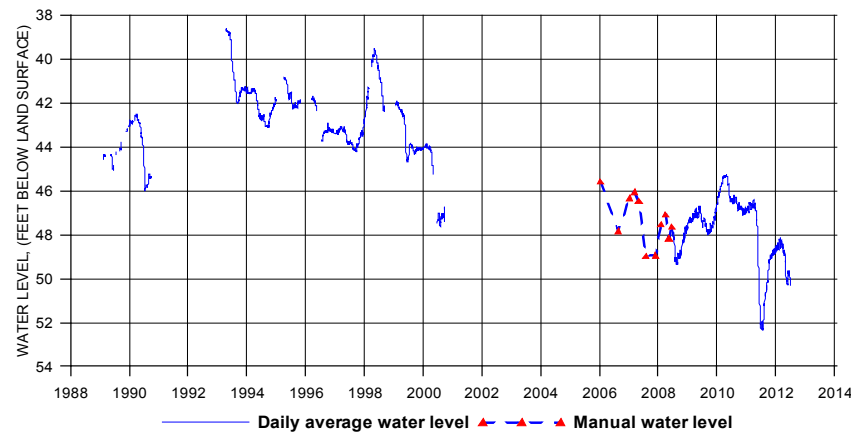

Figure 18. Daily average and manual water levels for BRN-0352 (Tertiary sand/Gordon aquifer; screened interval 278-288ft).

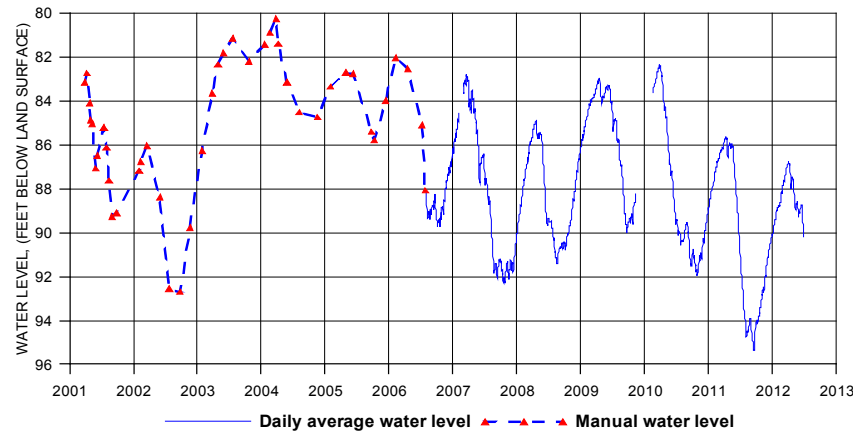

Figure 19. Daily average and manual water levels for ORG-0430 (Tertiary sand/Gordon aquifer; screened interval 205-265 ft).

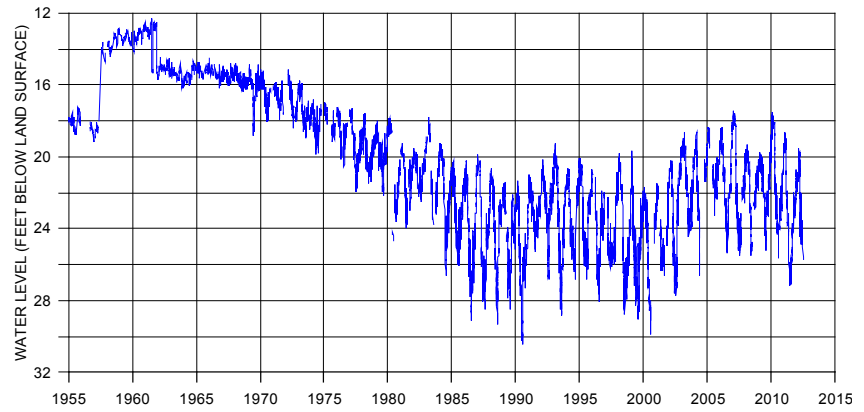

Figure 20. Daily average water levels for BFT-0101 (Floridan/ Upper Floridan aquifer; open hole interval 129-442 ft). seasonal fluctuations. The water level in well $\mathrm{CHN}$ 0044 (Figure 23) has declined about $20 \mathrm{ft}$ since the early 1980s, and well COL-0097 (Figure 24) has seen a decline of about $20 \mathrm{ft}$ since the late 1970s.

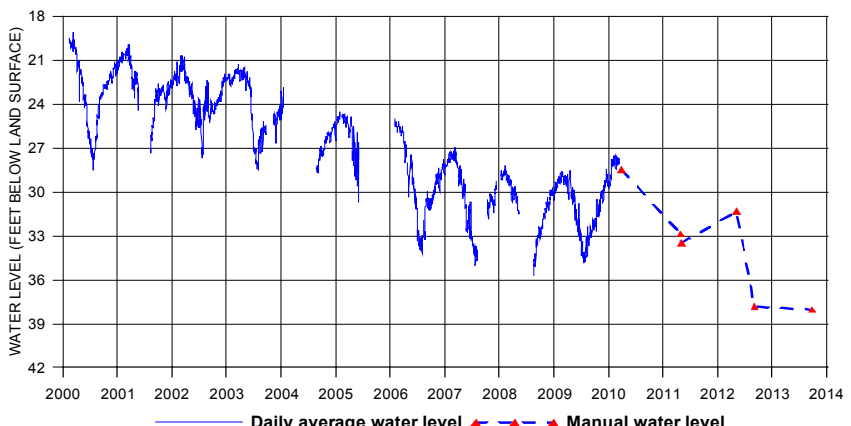

Figure 21. Daily average and manual water levels for COL-0301 (Floridan/aquifer zone within Gordon confining unit; open hole interval 516-545 ft).

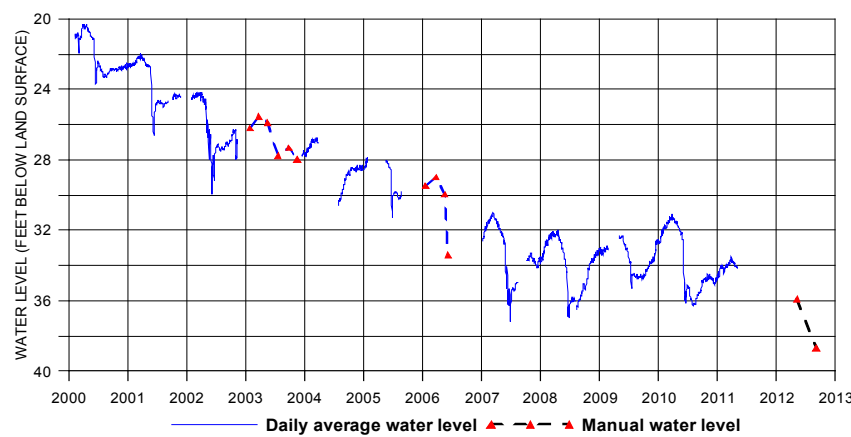

Figure 22. Daily average and manual water levels for CHN-0484 (Floridan/aquifer zone within Gordon confining unit; open hole interval 280-560 ft).

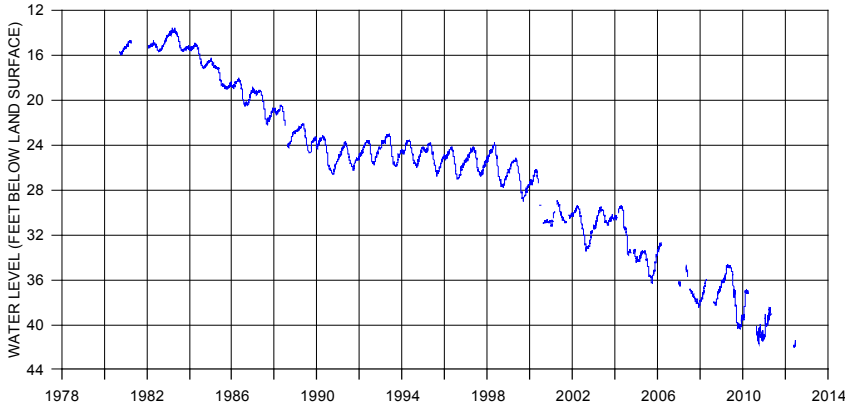

Figure 23. Daily average water levels for CHN-0044 (Floridan and Tertiary sand/Middle Floridan and Gordon aquifer; open hole interval 180-434 ft).

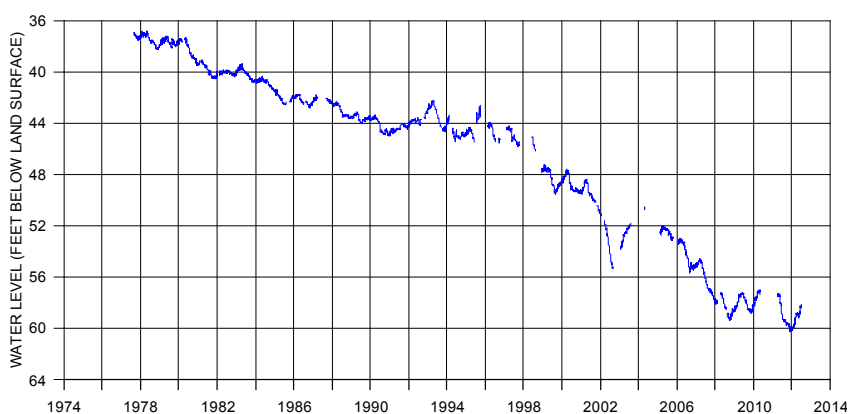

Figure 24. Daily average water levels for COL-0097 (Floridan/ Middle Floridan aquifer; open hole interval 132-342 ft). 


\section{DISCUSSION}

Long-term groundwater-level declines have been observed in each of the major aquifers in the state. These declines are likely a result of both drought and groundwater pumping. Many well sites experienced a strong response to the multi-year droughts of 19982002 and 2007-2008. However, while some wells experienced a recovery after these droughts, other well sites did not.

Seasonal fluctuations are evident at many wells owing to higher recharge rates in winter as compared to summer. In Colleton and Charleston Counties, as well as in Beaufort County, the larger fluctuations observed over the past several decades are likely the result of natural seasonal variations coupled with increasing rates of irrigation.

There are many challenges for the State's water managers in the interpretation of groundwater-level data throughout the state. First, water-level declines can be caused by drought and/or localized pumping for water supply and irrigation as well as from the cumulative effects of pumping over broader regions. In addition, uncertainties in recharge areas and recharge rates for the State's aquifers add to the complexity of understanding groundwater level behavior. Many of the wells in the network have only been monitored for 10 to 15 years and, hence, may lack a sufficient period of record from which to adequately evaluate trends. Lastly, despite having over 170 continuously monitored wells by DNR, DHEC, and the USGS, large areas of the state, particularly the middle coastal plain, currently have little to no continuous monitoring.

These challenges make it difficult to evaluate the significance of these observed water-level declines; however, these trends highlight the importance of maintaining a state groundwater-monitoring network and the establishment of long-term groundwater datasets. Future work should include adding wells in those aquifers and areas of the State where current monitoring is poor or nonexistent. In addition, a more detailed study on groundwater-level trends should be completed that takes into account climate variability and local/regional groundwater use. Such a study is needed to differentiate the effects of drought and groundwater pumping on water level behavior.

\section{LITERATURE CITED}

Aadland, R.K., Gellici, J.A., and Thayer, P.A., 1995, Hydrogeologic framework of west-central South Carolina: South Carolina Department of Natural Resources, Water Resources Division Report 5, 200 p. Agerton, K.E., Park, A.D., Gawne, C.E., and Wachob, A., 2007, Water resources data for South Carolina, 2000-2005: South Carolina Department of Natural Resources, Water Resources Report 41, 91 p.

Aucott, W.R., Davis, M.E., and Speiran, G.K., 1987, Geohydrologic framework of the Coastal Plain aquifers of South Carolina: U.S. Geological Survey WaterResources Investigation Report 85-4271, 7 sheets.

Gellici, J.A., Kiuchi, M., Harwell, S.L., and Badr, A.W., 2004, Hydrologic effects of the June 1998-August 2002 drought in South Carolina: South Carolina Department of Natural Resources, Water Resources Report 34, 49 p.

Gellici, J.A., and Lautier, J.C., 2010, Hydrogeologic framework of the Atlantic Coastal Plain, North and South Carolina, in Campbell, B.G., and Coes, A.L., eds., Groundwater availability in the Atlantic Coastal Plain of North and South Carolina: U.S. Geological Survey Professional Paper 1773, p. 49-162.

Harder, S.V., Gellici, J.A., Gawne, C.E., and Wachob, A., 2012, Groundwater levels in South Carolina, 2006-2010: South Carolina Department of Natural Resources, Water Resources Report 50, 154 p.

Harwell, S.L., Park, A.D., Hockensmith, B.L., and Gawne, C.E., 2004, Water resources data for South Carolina 2000-2001: South Carolina Department of Natural Resources, Water Resources Report 31, 86 p. Waters, K.E., 2003, Water levels in South Carolina-A compilation of historical water-level data: South Carolina Department of Natural Resources, Land, Water and Conservation Division Report 26, 300 p. 